\section{Literature, Law, and} Rhetorical Performance in the Anticolonial Atlantic

\author{
ANNE W. GULICK
}

"Literature, Law, and Rhetorical Performance in the Anticolonial Atlantic is an excellent contribution to a new wave of postcolonial analysis that is not bound by issues of genre, geography, or canonicity." -Michael Malouf, author of Transatlantic Solitaries: Irish Nationalism and Caribbean Poetics

THE OHIO STATE UNIVERSITY PRESS

\begin{tabular}{l|l} 
www.ohiostatepress.org & 800.621 .2736
\end{tabular}

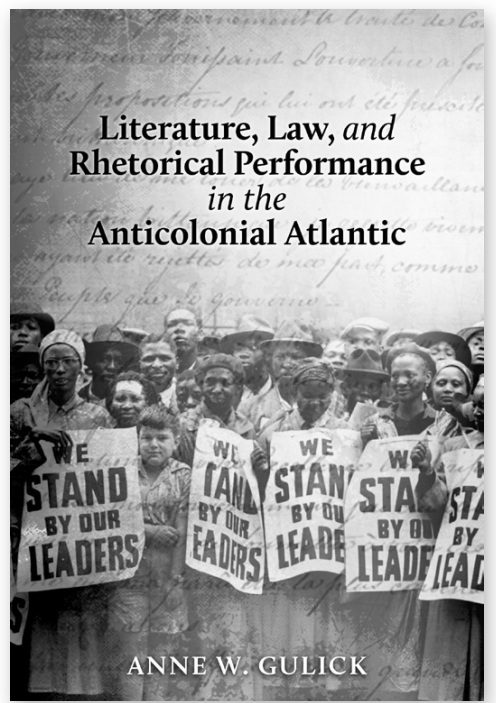

\$99.95 | cloth 978-0-8142-1302-5 


\section{Instructions for Contributors}

\section{PREPARING YOUR MANUSCRIPT}

Manuscript submissions to the journal should be between a maximum of 8,000 words, not including notes. On rare occasions, the editors will give consideration to a lengthier submission of exceptional quality. The text and bibliographic documentation of the manuscript must conform to the Chicago Manual of Style (CMOS), 16th edition. We require that authors use footnotes rather than endnotes and that they doublespace the entire manuscript.

Manuscripts must have a separate title page that includes the author's name, affiliation, e-mail address, postal address, an abstract of no more than 150 words, a list of keywords, and an author bio of no more than 50 words. The author's name should appear nowhere else in the manuscript. All references to the author's work in the text or notes should be in the third person.

In the footnotes, full bibliographical documentation must be given in the first reference. For example:

Bill Ashcroft, Gareth Griffiths, and Helen Tiffin, eds. The Post-colonial Studies Reader (London: Routledge, 1995).

Eric Auerbach, "Philology and Weltliteratur," Trans. Edward Said and Marie Said. Centennial Review 13.1 (1969): 1-17.

Karin Barber, "Literature in Yoruba," Cambridge History of African and Caribbean Literature, eds. Abiola Irele and Simon Gikandi. Vol. 1. (Cambridge: Cambridge UP, 2011), 357-78.

Dipesh Chakrabarty, Provincializing Europe: Postcolonial Thought and Historical Difference (Princeton: Princeton UP, 2000).

Henry Louis Gates, Jr., “Tell Me, Sir, ... What Is ‘Black' Literature?” PMLA 105.1 (1990): 11-22.

In subsequent references use "ibid." when the reference is clear; in other cases, use a shortened version of the main title. (The journal's house style does not use "op. cit."). For example:

Ibid., 65-66.

Auerbach, "Philology," 12.

\section{SUBMITTING YOUR MANUSCRIPT}

Send an electronic copy, along with a cover letter, to this address:

The Editor

Cambridge Journal of Postcolonial Literary Inquiry

pli@cambridge.org

In the cover letter, the author should state that the manuscript will not be submitted to another journal until PLI's evaluation is completed.

\section{PROOFS}

Authors will be sent proofs via email. They should mark the PDF proof electronically or in hard copy and are requested to return their proof corrections by email within three days of receipt. Please let the Editorial Office know if you are likely to be away for any extended period at that time, or if the proofs should be sent to anywhere other than your normal email address. The publisher reserves the right to charge authors for excessive correction of nontypographical errors.

Individual articles will publish online ahead of print publication as a FirstView article. Articles are corrected and published online as soon as possible after they are corrected. This means that articles are published very quickly and publication is not delayed until they can be included in a print issue.

Authors of articles and review essays (but not book reviews) will receive a .pdf file of their contribution upon publication. 


\section{CAMBRIDGE JOURNAL OF POSTCOLONIAL LITERARY INQUIRY}

"Our Supreme Objective": Nehru, A Suitable Boy, and the Moderation of Feeling

Bede Scott

Transcultural Aesthetics and Postcolonial Memory: The Practices and Politics of Remembering in Tan Twan Eng's The Garden of Evening Mists

Angelia Poon

Postclassical Poetics: The Role of the Amatory Prelude for the Medieval Islamic Republic of Letters

Sahar Ishtiaque Ullah

Self-Consumption and Compromised Rebirth in Dabydeen's "Turner"

Veronica J. Austen

\section{EXPLICATION DE TEXTE}

Against Mastery: Teaching Thomas King's Green Grass, Running Water

Robert McGill

\section{B00K REVIEWS}

Feminist Visions and Queer Futures in Postcolonial Drama: Community, Kinship, and Citizenship by Kanika Batra

Anuradha Marwah

Ingratitude: The Debt-Bound Daughter in Asian American Literature by Erin Khue Ninh

Y-Dang Troeung

Realism, Form, and the Postcolonial Novel by Nicholas Robinette

Weihsin Gui

Russian Orientalism: Asia in the Russian Mind from Peter the Great to the Emigration by David Schimmelpenninck van der Oye

Ewa M. Thompson
Cambridge Journals Online

For further information about the journal,

please go to the publisher's journal web site at journals.cambridge.org/pli
CAMBRIDGE UNIVERSITY PRESS www.cambridge.org 